Article

\title{
Responses of Korean Buddhism to the Ethos of Contemporary Korea: Three Discourses in the Wake of Modernization
}

\author{
Woncheol Yun ${ }^{1, *}$ and Beom Seok Park ${ }^{2}$ \\ 1 Department of Religious Studies, Seoul National University, Seoul 08826, Korea \\ 2 Center for Religious Studies, Seoul National University, Seoul 08826, Korea; vine0427@snu.ac.kr \\ * Correspondence: yunwc@snu.kr; Tel.: +82-10-659-7069
}

Received: 30 September 2018; Accepted: 21 December 2018; Published: 24 December 2018

\begin{abstract}
The revival of Buddhism in Korea began in the 20th century as the nation suffered a downfall from the colonization of the Japanese Imperialists. In this chaotic time of social turmoil, transformation into a modern nation resulted not from a natural flow of events but rather from an articulation through a series of discourses on Korean identity. The modernization process in Korea was precipitated by the Japanese colonialism, thereby adding to the complexity during the time of social transformation. In this paper, we have reviewed the three major discourses of Korean Buddhism in the wake of modernization. The following discourses were attempts to deal with the problems faced by the Buddhist community during modernization: the discourse on secularity and social participation, the discourse on modernity centering on the issue of modifying precepts, and the discourse on identity contemplating the originality of Korean Buddhism. The fact that the old controversies concerning precepts continue even to this day in Korea might be regarded as a proof of the vibrant dynamics of contemporary Korean Buddhism. Accordingly, the next unavoidable discourse regarding Korean Buddhism would be on whether and how it can adapt itself to contemporary society, along with what part it will play in the forthcoming society.
\end{abstract}

Keywords: Korean Buddhism; modernization and Buddhism; patriotic Buddhism; marriage of monks; all-embracing Buddhism

\section{Introduction}

Ever since Buddhism was first introduced in Korea at the end of the 4th century, the Buddhist sentiment has taken deep roots in the Korean way of thinking and lifestyle. In modern-day Korea, traditional religions and new religions intermingle without much conflict. This balance in religious co-existence could come from a Buddhist influence, which emphasizes tolerance and generosity. Nonetheless, Buddhism has not always been so welcomed throughout Korean history. From the foundation of the Joseon dynasty (조선 朝鮮, 1392-1897) with Confucianism as its national ideology, Buddhism was persecuted for five hundred years. Under such coercion, many Buddhist temples and monks chose to go into hiding, literally and figuratively, for survival.

It is quite ironic that the revival of Buddhism in Korea began in the 20th century during which the nation suffered a downfall from the Japanese Imperialists' invasion. During the colonization, the new influence of Japanese Buddhism advanced. The Buddhist community became more accepted in the society, and there was a significant rise in the social status of Buddhist monks. Such changes brought about a surge of vibrancy in the Buddhist community. During this time, some of the Buddhist community led resistance against Japanese rule, while there were others who appealed to the pro-Buddhist Japanese colonialists to bring about a religious revival. To classify the activities of 
the era in dichotomy such as pro- versus anti-Japan, or Korean versus Japanese Buddhism would be simplifying and therefore distorting a complex reality. Even though it is true that there was a demand for modernization through provocation of the Japanese invasion, it cannot be denied that there were innumerous controversies surrounding the course of transformation.

We shall contemplate the discourses in Korean Buddhism brought up during the process of modernization by dealing with major controversies of the time. To fully understand the discourses, it would be crucial to comprehend the hardships that the Buddhist community experienced while responding to social changes. It seems that the Buddhist community has taken the best available option during the time of chaos by striving for a breakthrough rather than choosing one between the opposing positions.

In this paper, we shall examine the history of discourses by focusing on major controversies throughout Korean modernity. As some of these discussions are still relevant, this paper will hopefully contribute to a better understanding of Korean Buddhism in today's world.

The first of such topics is the controversy surrounding Hoguk Bulgyo (호국불교 護國佛教)—literally 'national defense' or patriotic Buddhism-as a discourse on secularity. The concept is represented by the phenomenon of Korean Buddhist monks taking arms against foreign invaders in times of national crisis. As the significance of the term might be open for discussion, by 'secular', we refer to instances when Buddhism steps out of its seclusion to participate in social and political affairs. Secondly, we will discuss the issue of monks' marriages as a discourse on modernity. As modernization in Korea was precipitated by the Japanese colonization, Japanese influence in Korean modernity caused social confusion. The controversy surrounding the marriage of Buddhist monks is a good example. The third topic is the controversy of Hoetong Bulgyo (회통불교 會通佛教)—literally, 'inclusive' or consolidation Buddhism, a name given to emphasize the all-embracing characteristic of Korean Buddhism-as a discourse on identity. This discourse aims to discuss whether there is a trend of Buddhist ideas particular to Korean society, independent from that of China or Japan.

The three discourses touch upon secularity, modernity, and identity, which are the topics the Buddhists in Korea have contemplated over and debated on until recent years. In discussing the controversies, it is essential to understand the socio-political background of modernization in 20th century Korea. During the colonial period, the Japanese government proceeded with the modernization of Korea in order to exploit resources and use Korea as a bridgehead for its advance on the continent. During the national crisis of Japanese occupation, the biggest challenge of Korean Buddhism was to survive. For a way of survival, it had to choose between adapting itself to the new social environment or resisting to changes. On one hand, the three discourses were responses of the Korean Buddhist community to the crises generated by Japanese occupation. On the other hand, they were also the Korean Buddhist community's efforts to deal with the inevitable issues that stemmed from modernization. Such issues show Korean Buddhists' active engagement in resolving issues from the fast-changing secular society, defining and preserving the Buddhist traditional identity, and creating new dynamics. These efforts can be construed as proof of vibrancy in contemporary Korean Buddhism.

\section{Background for the Discourses Surrounding Modern Korean Buddhism}

At the beginning of the 20th century, Korean Buddhism was not in a state to compete with foreign influences. It was forced to accept the intervening powers of the West and the Japanese Imperialists. Although the Joseon dynasty's ban that kept Buddhist monks/nuns from entering the capital was lifted and there was a slight improvement in the social status of the cleric, the revival of Korean Buddhism was subtle compared to the sudden rise of Christianity. Supported by the powers of the West, Christianity symbolized Westernization. During this era, Westernization meant modernization (Kim 2003, p. 184). For supporters of modernization, all obstacles to modernization—whether stubborn Confucianism, superstitious Shamanism, or the idle Buddhists-were equally subject to eradication (Park 2004, p. 238; Lee 2006, p. 279) 
The Protestants proved to be a great threat to Buddhism, as they were aggressive in their proselyting and preached incompatibility with other religious beliefs. At the time, the theory of social evolution was the accepted norm, though it was hardly for the purpose of enlightenment or civilization; it was rather used as a justification for colonialism. Under the theory of evolution, the survival of the fittest can also be applied to human society. From such a perspective, the existence of or exploitation by colonizers can be justified. The Buddhist community attempted to interpret social evolution theory as a method of overcoming outdated notions and moving towards equality, but there wasn't much outcome. Such failure comes from the limits of the theory of evolution itself and its discord with the Buddhist worldview.

In short, as Christianity and social evolution theory were used wrongfully to justify Western colonialism, Japanese Imperialists imitated the West and approached the colonization of Joseon in the name of modernization. Korean Buddhism during the modernization period was caught between the two major forces of Western and Japanese colonialism. It had to deal simultaneously with the growing force of Christianity and the intervention of Japanese Buddhism. During the modernization under colonization, Korean traditions were looked down upon as outdated evils. Likewise, the profound philosophy of Buddhism was degraded as a mere folk religion (You 1985, p. 241).

In addition to such social turmoil, modernity also gave rise to troubles within Buddhism. Traditional Korean Buddhism centers on a firm belief in asceticism and truth seeking. It has put emphasis on them more than any other religion has. Rather than accustoming oneself to the world, one should be willing to go through extreme penance in order to achieve enlightenment on the ultimate significance of life. To leave one's home and become a Buddhist monk/nun means to leave behind all secular pleasures and to embrace such asceticism. Owing to such disconnection from the outside world, the Buddhist community was at times slow to respond to social changes, and its reactions were sometimes inappropriate. In the time of social transition such as the modernization period, there was no clear standard for how the Buddhist community should take part in such changes, resulting in over-intervention or utter insensibility.

Another factor is that Buddhist sentiments have influenced the Korean mind and vice versa for a couple of millennia. It is a common saying that Koreans are innately multi-religious. They are Confucians in family matters, but take Buddhist tendencies when contemplating life, while also taking a Shamanist view of fate. The three religions have blended in a balanced way. Some believe that is why Koreans have so peacefully adjusted to the current multi-religious society. The inclusive, tolerant, and harmonious religious tendencies of the Korean people are often attributed to the influence of the Buddhist worldview of infinite mercy. On the other hand, the fact that Korean Buddhism emphasizes harmony and consolidation compared to other Buddhist cultures seems to have resulted from the Korean tendency of tolerance (Choi 2017, p. 210; Lee 2007, pp. 137-41, 165-66).

It would be impossible to sum up the course of change that Korean Buddhism has gone through in a few discourses. Nonetheless, we shall seek to sympathize with the anguish the Buddhist community experienced during the social transformation by discussing some key words that can encapsulate the major challenges of the modernization process. These key words would lead to three controversies concerning the armament of Buddhists to defend the nation, marriage of Buddhist monks, and the Korean Buddhist tendency of consolidating. Each controversy leads to the discourses of secularity, modernity, and identity.

\section{Discourse on Secularity: The Controversy Surrounding Hoguk Bulgyo}

"Hoguk Bulgyo" is a term often used to illustrate Korean Buddhism, but it is a controversial one. Hoguk, meaning "defending the nation," emphasizes the role of the Buddhist community to protect the country in times of crisis. Is this a necessary part of being Buddhist in Korea? For the Buddhist community, this term may be accepted as appropriate. Any duty or responsibility to defend the nation arises as an expedient means to protect the dharma or to save living beings, but not as an end. In other words, the term must be understood as a means to realize the Buddhist dharma. 
Nevertheless, the term hoguk is used in the context of what the nation demands of the Buddhist community. From the nationalist point-of-view, the Buddhist community and believers are the components of the state; they are on the receiving end of government protection and it is natural they be asked to be loyal to the state when the need arises (Kim 2012, pp. 79, 82). In fact, Buddhism has served to consolidate the sovereign power since the Three Kingdoms era and has won a name for taking an active role in fighting back foreign attacks. There is no denying the part, both spiritual and physical, that the Buddhist community has played in resisting aggressors. For example, Buddhists carved the Tripitaka Koreana, often called the Palmandaejangyeong (팔만대장 경 八萬大藏經), in the hope of repelling the Mongolian invasion of the Goryeo dynasty (고려 高麗, 918-1392). Troops of monks fought against the Japanese and the Chinese invasions during the Joseon dynasty.

From the Buddhist community's perspective, national defense was to some point used as a tool for propagation. While it would have been ideal to find a method of evangelism on its own, government support is a momentum that is incomparable with any effort within the Buddhist community. Nonetheless, because of this compromise with political power, the original Buddhist purpose of saving living things has somewhat diminished for the sake of advocating the regime or justifying the ruling class (Kim 2000). Instead of fortifying the ascetic tradition, such social participation might have the effect of satisfying only the interests of the Buddhist ruling class who wish to conspire with political powers.

On the other hand, there are also quite positive evaluations of the Buddhist contribution to the protection of the Korean nation. Since Buddhism was introduced to Korea and officially recognized by royal courts during the Three Kingdom period, the Buddhist community's engagements in social activities have never been ceased. It is especially argued that Buddhist ways of social participation to defend the nation should not be confused with the attempts to advocate certain ideologies or to support particular social classes (Ko 2013, pp. 90, 110-12, and passim). It is also argued that this tendency of social participation led to the independence movement in the Japanese colonial era and to the Buddhist democracy movements in the modern era such as Minjung Buddhism (민중불교 民衆佛教), Seonwu Doryang (선우도량 善友道場), and Jeongto-hoe (정토회 淨土會) (Park 2010b, p. 48; Lee 2010, pp. 49-52).

The Buddhist community, oppressed throughout the Joseon dynasty, strove to find its identity between the two choices of pro-Japan or anti-Japan during the colonization. For this issue, the cause of 'national defense' can be played either way. 'National defense' seems to have been a choice of survival rather than a result of contemplation and discernment over whether one should loyally protect the state. One might guess that there were more pro-Japan priests than the anti-Japan priests because such choice was a matter of survival rather than a 'national defense' issue.

Political participation of priests after the liberation in 1945 seems to have been a choice for safeguarding the possessions and ensuring the safety of the Buddhist community in the post-war chaos. However, it is questionable whether such participation may be considered an aspect of Hoguk Bulgyo. Furthermore, the choices the Buddhist community made under the military regime, namely siding with the government authorities rather than fighting in resistance, has caused much shame and regret. Before contemplating whether survival or national safety is at the heart of Hoguk Bulgyo, one is forced to ask whether such choices served to "save all living beings."

Even if the fundamental motivation behind Hoguk Bulgyo was to save all living beings, it is difficult to escape the criticism that it might be misused or misconstrued to defend certain ideology after all. At times, the term Hoguk Bulgyo, like Minjok Bulgyo (민족불교 民族佛教 nationalist Buddhism) or Bangong Bulgyo (반공불교 反共佛教 anti-Communist Buddhism) might appear to be the result of Buddhist secularization or political corruption. If hoguk, or national defense, is not for the defense of dharma or the defense of all living things, it might become nothing more than support for nationalism. It is simply not permissible that the cause of defending a country becomes the ultimate purpose or a value beyond that of saving all living things. It would be against the spirit of Buddhism to show mercy only towards the ruling class of the state. 
Rather than discussing the concept of Hoguk Bulgyo itself, it would be more useful to explore its role, that is, the aspects of its development or its functions regarding certain political powers. It would not be ideal to contain Korean Buddhism within the narrow concept of Hoguk Bulgyo, or to glorify it by selectively displaying the positive side. A lively discussion of how Hoguk Bulgyo differs from the narrow-minded nationalism or the political empowerment of Buddhism is called for.

\section{Discourse on Modernity: The Controversy Surrounding Marriage of Monks}

In dealing with the discourse on modernity in the early 20th century Korean Buddhism, one cannot leave out the topic of the marriage of monks. It cannot be denied that the Korean Buddhist community was deeply influenced by Japanese Buddhism during the colonization period. The biggest issue in accepting Japanese influence was whether to allow the marriage of Buddhist monks. Traditionally, entering the monkhood means leaving home, renouncing the world, and focusing on ascetic practice. According to traditional views, monks cannot marry while practicing asceticism. For convenience's sake, we shall call those belonging to the order that allows marriage as the 'married monks' and those who do not as bhikkhus - the Pāli word for fully ordained celibate Buddhist monks.

The background to the appearance of the married priests in Korean Buddhism is twofold. First is the direct influence of Japanese Buddhism. In Japanese Buddhism, marriage is allowed for the monkhood. Korean Buddhism could not avoid Japanese influences under colonization. In addition, the new generation of Korean monks who had studied abroad in Japan were voluntarily drawn to the trend. In order for the married monks to expand their influence, they had to compete for power and properties with the bhikkhus. Therefore, conflicts between the two groups were inevitable. It was only natural that the Japanese government officials in Joseon favored the pro-Japanese married monks.

Nonetheless, there was a second influence from within the Buddhist community which was making an effort to adapt to modern society. Toward the end of the 19th century, the theory of social evolution had made a huge impact on Korean society. The concept of 'evolution' was applied to all areas of society, and the Buddhist community itself felt the need to change and adapt (Kim 2011, p. 275). For some of the Buddhist reformists, the marriage of monks was justified as the modern 'evolution' of Buddhism.

Young-Un Han (한용운 韓龍雲, 1879-1944), a major reformist monk, gave several reasons why monks' marriage should be allowed (Han 2016). He claimed that as the world is changing, the precepts should be applied flexibly according to the social settings. Moreover, as carnal love between man and woman cannot be relinquished, marriage should be allowed for the sake of the further development of Buddhism. As a 'modern value,' allowing monk's marriage signifies that human carnal desire should be accepted. Such understanding is the direct opposite to the Buddhist ideal of extinguishing such desires in nirvana. To his contemporaries, it must have come across as a ground-shaking idea that allowing priests to marry could modernize the Buddhist institution by affirming human desires.

As is well known, marriage of monks in Japan has a long history. However, since the Meiji government in Japan officially allowed monks to eat meat and marry in 1872, it has become quite natural for Buddhist monks in Japan to have a wife and create a family. It has also become part of the tradition for the offspring of the monks to inherit the temple. An interesting aspect is that in Japan, there was no such controversy and conflict over meat-eating and marrying (Je 2014, p. 249). How the tradition of the marriage of monks settled down so easily in Japan will be a matter that will have to be dealt with elsewhere, but it seems that Japanese culture was more accepting of the idea, as opposed to the fierce debate over allowing the marriage of monks in Korea.

The controversy of the marriage of monks that became prominent during the Japanese colonization seems to be a compound of two issues. The first is whether the marriage of monks conforms to the fundamental precepts of Buddhism, apart from the modernity issue underlined by the controversy. Secondly, monk marriage is a Japanese tradition, therefore many found it unacceptable in Korea. These two were intermingled issues in the minds of many and were used together to criticize the married monks from the bhikkhus' point-of-view. The marriage of monks was condemnable as violating 
Buddhist precepts while also being pro-Japanese. The married monks, on the other hand, believed that allowing the marriage of monks is a crucial aspect of 'modernizing' Buddhism and making it sustainable in a new era.

When all is said and done, this effort to modernize Buddhism and to override the monopoly of bhikkhus monkhood does not seem to have left a positive effect. The biggest problem was that the married monks, while maintaining the prerogatives of monkhood, could not surrender the comfort of secular life either. The fact that the conflict between the two groups of monkhood appeared nothing more than a dispute over the riches of the temple in the eyes of the public only added to the negative sentiment. Had the demands for priest marriage risen from the purpose of Buddhist modernization eventually leading to fundamental precept reform, then it would not have remained as a mere conflict between the two groups within monkhood. Korean Buddhist leaders failed to win the affirmation of the general Buddhist community because the reform suggested by the modernists was not substantial enough to overcome the criticism that allowing the marriage of monks was simply a pro-Japanese move.

Furthermore, Syngman Rhee, the first president of the Republic of Korea (a.k.a. South Korea), established after liberation from Japanese colonial regime, released a series of presidential instructions that monk marriage was a Japanese legacy and thus should be eliminated to revive the authentic Korean Buddhism. He needed to establish the legitimacy of his government against the communist North Korea, and the most important condition for it was to show an anti-Japanese stance on any given issue. President Rhee's instructions were fatal blows to the reformists' advocacy of monk marriage as a way of 'modernization.'

In today's Korea, the Jogye Order (조 계 종 曹溪宗) of celibate monks and nuns is the largest, but the Taego Order (태고 종 太古宗), which allows the married to be ordained without leaving home, is of similar scale in terms of the number of monks. In recent years, there has been no visible conflict between the two groups of monkhood, as the institutions of both orders have become firmly established. The married and the celibate groups co-exist peacefully. However, the issues concerning the modification of precepts, including monks' meat-eating as well as marriage, remain controversial.

\section{Discourse on Identity: The Controversy Surrounding Hoetong Bulgyo}

In discussing the identity of Korean Buddhism, the controversy concerning Hoetong Bulgyo (회 통 불교 會通佛教) is something that never fails to be mentioned. The term hoetong means peacemaking among the conflicting opinions of different orders within Buddhism. It can also be applied to external relations with different religions.

It was Nam-Seon Choe (최남선 崔南善, 1890 1957) who explicitly defined Korean Buddhism as Hoetong Bulgyo (Choe 1930). According to him, the characteristic of hoetong can be found in various aspects throughout the history of Korean Buddhism beginning from Wonhyo (원효 元曉, 617-686) of the Three Kingdoms period. Wonhyo is considered the first philosopher to attempt to consolidate conflicting and controversial Buddhist precepts into a single fundamental purpose (Yun 2009, p. 107; Kim 2007, p. 38). In fact, successors such as Uicheon (의 천 義天, 1055-1101) and Jinul (지눌 知訥, 1158-1210) consistently suggested that Seon (선 禪) and Gyo (교 教) Buddhist orders-with respective emphasis on practice and precept—should be consolidated. Such opinion is relevant to the tendency for hoetong.

This hoetong point-of-view is again made apparent during the Joseon dynasty when interacting with other religions. In order to survive Joseon's anti-Buddhist policies, the Buddhist community chose to co-exist in peace with other religious beliefs such as Confucianism, Daoism, and Shamanism. Rather than drawing attention to its distinguishable traits and causing conflict, Buddhists supported the hoetong point-of-view that all religions fundamentally serve a single purpose.

To this day, with such a historical background, it has long been considered fact that the Hoetong Bulgyo sets aside Korean Buddhism from other Buddhist cultures. Under colonization, Koreans going through hard times needed a representation of national pride to distinguish themselves from Chinese or 
Japanese. Hoetong Bulgyo seems to be a product of such necessity (Choi 2013, pp. 103, 105-6 and passim). Scholars pondered what would make Korean Buddhism unique from those of Japan or China-as before the Japanese invasion, Korea was under heavy influence from Chinese Buddhism-and came up with this idea.

Nam-Seon Choe's opinion was accepted by some scholars, but it failed to gain popularity at the time. His idea began to be regarded as an authentic characterization of Korean Buddhism after liberation from Japan and during the 1970s and 1980s with the advocacy of nationalist articulation of what Korean identity was. Since then, Nam-Seon Choe's Hoetong Bulgyo has been regarded as a central concept for the identity of Korean Buddhism (Shim 1989, pp. 152-54).

It was a series of scholars in the 1980s that started the controversy, criticizing the characterization of Korean Buddhism as Hoetong (or Tong) Bulgyo. According to them, the term Tong Bulgyo is not an outcome of meticulous research but rather an ideology that serves nationalistic needs (Shim 2000). To judge by the historical background, the concept was first formed to better emphasize the originality and superiority of Korean Buddhism against the Japanese influence of modernization. Criticism against Tong Bulgyo suggests that the scholars accepted this point-of-view without much critical thinking, even though it is difficult to find a consistent point of hoetong throughout the history of Korean Buddhism. (Shim 1989, pp. 154-55).

In this context, Eun-su Jo argues that the concept of hoetong itself does not refer to a characteristic idea nor point to any specific and distinctive value. To characterize Korean Buddhism as Hoetong Bulgyo amounts to regarding Korea Buddhism as a featureless tradition with no identifiable property. In other words, the concept is empty (Cho 2000; Cho 2004, p. 51).

Robert Buswell also criticized that the concept of 'Korean Buddhism' is a product of a nationalist perspective formed during the Japanese colonial period of the 1930s, and that it is wrong to try to find a unique Korean Buddhist tradition. According to him, traditional Korean monks have established their own identities in the universal system of Buddhism, in terms of their positions within sectarian dharma lineages rather than nationalities. Therefore, it is anachronistic and fictional to define the identity of Korean Buddhism as Hoetong Bulgyo (Buswell 1998, pp. 103-4).

The major issue of the Hoetong Bulgyo debate is whether hoetong is a distinctive enough idea to consider it as the identity of Korean Buddhism. Those who criticize Hoetong Bulgyo claim that the general disposition of Buddhism is consolidating or peacemaking, so that hoetong cannot be considered an idea particular to Korean Buddhism. (Kim 2007, pp. 38-49). The hoetong principle is already included in the Avatamska (Hua-yen 화엄 華嚴) worldview of "neither one nor two" (不一不二) or "one is many, many is one" (一㴧多多郎一). Wonhyo's philosophy of hwajaeng (화쟁 和猙 harmonizing disputes), often considered the commencing point of Hoetong Bulgyo, does not differ greatly from the general Buddhist philosophy of India or China.

It surely is a valid point that defining the traditions of Korean Buddhism in a single term of Hoetong Bulgyo is an unjust simplification of innumerous characteristics and dynamic changes that compose the history of Korean Buddhism. Nonetheless, it is undeniable that Korean Buddhism traditionally tends to consolidate the conflicting opinions of different orders rather than to show their distinctive colors, as opposed to Chinese Buddhism, which has the tendency to classify and enumerate the various Buddhist orders. As in the case of Uicheon's Gyogwan gyeomsu (교관겸수 教觀兼修) or Jinul's Jeonghye ssangsu (정혜쌍수 定慧雙修)—both insist that doctrinal studies and meditation practice should be proceeded together-the tendency for hoetong among the major Korean Buddhist thinkers is quite apparent.

Scholars who object to characterizing Korean Buddhism with the term hoetong commonly focus on the idea that this concept is a product of nationalism during the Japanese colonial period. Even though it is true that Hoetong Bulgyo has been articulated and advocated in response to the particular social demand, there are a large number of thinkers in the history of Korean Buddhism whose dispositions clearly show the legacy of hoetong. 
It is a natural and universal course for an ideology or culture to go through stages of division and consolidation as time passes. Some traditions show more emphasis on division and others on consolidation. China might be a case for the former, while Korea for the latter. It would be problematic to define the two cultures in a binary way, but if such classification helps to understand the two cultures better, then it is acceptable as one among many methods of illustration. Rather than defining or denying Korean Buddhism as hoetong, it would be more productive to discuss how and in what way Korean Buddhism developed such tendencies.

It is not easy to comprehend the identity of even a single individual; how much more difficult would it be to define an identity of an entire culture? It is not that the identity of a group can be granted from outside the group with objective data and basis, nor can it be decided on through discussion and general consent of its members. It requires the passage of time in which such an identity can be naturally accepted from within and without. The fact that there is still controversy concerning the identity of Korean Buddhism signifies that we are still going through a stage of growth and development. Korean Buddhism still seems to be in the midst of active dispute and transformation.

\section{Conclusions}

In this article, we have discussed the controversies of Korean Buddhism during modernization through three major discourses: the first discourse on secularity, that is, the propriety of social participation; the second on modernity, centering on the issue of modifying precepts; and the third on the identity of Korean Buddhism, especially regarding the uniqueness of Korean Buddhism. The discourses could be considered as attempts to grasp the challenging problems faced by the Buddhist community during the modernization era. The experience of modernization in Korea was forced by Japanese colonialism, causing even more complexity (Park 2010a, p. 2). For Koreans, modernization did not begin from within nor proceed as a natural flow of events. As modernization was advanced by an external force, Korean society underwent a series of challenging controversies and social conflicts during the transformation.

In the three discourses, we can detect Buddhist thinkers' anxiety for breakthroughs in seeking the survival of Buddhism. Longing for growth during the rapid modernization can also be seen. Some wanted Korean Buddhism to revive and remain faithful to the legacies of the past, while others argued for its modern transformation. Conflicts between them could be seen in almost every single debate of each discourse. The former were pro-'Hoguk Bulgyo ideology' in the discourse on secularity, while the latter argued for allowing the marriage of monks in the discourse on modernity. The controversy surrounding the Hoetong Bulgyo concept was an effort to define the identity of Korean Buddhism on one hand, but may also be understood as a kind of alternative solution to the concerns for traditional legacy and those for modernity.

Compared to the intensity of such controversies during modernity, Buddhism seems to have reacted rather passively to contemporary social issues. During the 1970s and the 1980s, when the whole peninsula was in an uproar of pro-democracy movements, Buddhism sided with the oppressive and authoritarian government rather than with the people. It would be difficult to get over the past when Buddhism stood on the side of the governing ideology, as opposed to Catholic and Protestant leaders who took an active part in the resistance against government oppression. However, the fact that a considerable number of believers and intellectuals of the Buddhist community also took part in the social activism should be noteworthy and considered as a wake-up call for Buddhist leaders.

So, what caused such a decline of Buddhist participation in social issues? One reason may be its principle against secular participation, and another may be found in its loosely knit community. According to a recent religious census in South Korea, even though the Buddhist population has been in decline, its number is still on the level with the major religious groups of Catholics and Protestants. Nonetheless, compared to its Christian counterparts, the network among Buddhist believers is quite weak, making it difficult for the Buddhist community to congregate or reach a consensus. 
As seen in other religious groups as well, the growth in the religious population is proportionate to the expansion of social influence. The future prosperity of Buddhism relies on converting the anonymous Buddhists to active Buddhists, as many Koreans who harbor pro-Buddhist sentiments do not identify themselves as believers. The Buddhist community needs to actively participate in current social issues, especially those concerning the minorities and the underprivileged. Suggesting a Buddhist solution in the spirit of 'saving all the living beings' might be a new channel of social participation for the Buddhist community.

Funding: This research received no external funding.

Conflicts of Interest: The authors declare no conflicts of interest.

\section{References}

Buswell, Robert E., Jr. 1998. Imagining 'Korean Buddhism': The Invention of a National Religious Tradition. In Nationalism and the Construction of Korean Identity. Research Monograph 26. Edited by Hyung Il Pai and Timothy R. Tangherlini. Berkeley: Institute of East Asian Studies, University of California, pp. 73-107.

Cho, Eunsu. 2000. Recognition of Korean Buddhist History Focused on 'Tong Buddhism' Discourse. The Buddhist Review. 21. Available online: http:/ / www.budreview.com/news/articleView.html?idxno=335 (accessed on 13 August 2008). (In Korean)

Cho, Eunsu. 2004. The Uses and Abuses of Wonhyo and the "T'ong Pulgyo" Narrative. Journal of Korean Studies 9/1: 33-59.

Choe, Nam-Seon. 1930. Korean Buddhism: Its Position in Cultural History of the East. Seoul: Joseon Bulgyo cheongnyeon hoe, Available online: http:/ / rosetta-app.snu.ac.kr:1801/delivery/DeliveryManagerServlet? dps_pid=IE1668681 (accessed on 30 November 2018). (In Korean)

Choi, Byung-Hon. 2013. Systematic Recognition of Korean Buddhist History and Understanding Methodology. In Introduction to Korean Buddhist History. Edited by Byung-Hon Choi. Seoul: Jisik-Sanup Publications, vol. 1, pp. 85-106. ISBN 9788942311668. (In Korean)

Choi, Ju Youl. 2017. A Study on Korean Values and Religious Culture in the Multicultural Era. The Journal of Saramdaum Education 11/1: 27-42. (In Korean)[CrossRef]

Han, Youngun. 2016. Treatise on the Restoration of Korean Buddhism (Joseon Bulgyo Yusinnon). In Tracts on the Modern Reformation of Korean Buddhism. Translation and Introduction by Pori Park. Seoul: Jogye Order of Korean Buddhism, pp. 96-204. ISBN 978897801464994220. First published 1910.

Je, Jum-Suk. 2014. The Colonial Joseon and Buddhism. Maha Boddhi Thought 22: 241-78. (In Korean)

Kim, Jong-Man. 2000. Reflections on the Patriotic Buddhism. The Buddhist Review. 3. Available online: http: / / www.budreview.com/news/articleView.html?idxno=305 (accessed on 20 November 2018). (In Korean)

Kim, Do-Hyung. 2003. The Expansion of Civilization and Enlightenment Theories during the Period of the Great Han Empire. Korean History Research 121: 171-204. (In Korean)

Kim, Sang-Hyun. 2007. The Identity of Korean Buddhism within the Context of East Asian Buddhism. Buddhist Studies 27: 35-58. (In Korean)

Kim, Sang-Hyun. 2011. Buddhism and the Modern History of Korea. Journal for the Buddhist Studies 60: 263-89. (In Korean)

Kim, Sun-Seok. 2012. Reconsideration of the Patriotic Buddhism in the Korea (sic.) Modern History: Historic Example and Theory. Maha Boddhi Thought 17: 75-102. (In Korean)

Ko, Young-Seop. 2013. 'Buddha Dharma Protection' in National Buddhism and 'State Protection' in Engaged Buddhism. Buddhist Studies 64: 89-116. (In Korean)

Lee, Jae-Hun. 2006. Recognition of Other Religions in Modern Korean Buddhism. The Development and Character of the Modernization of Buddhism. Edited by the Institute of Buddhist Studies, Jogye Order of Korean Buddhism. Seoul: Jogye Order Publishing, ISBN 8986821540. (In Korean)

Lee, Won-Gue. 2007. On the Characteristics of the Religious Culture of Korea. Theology and the World 60: 129-71. (In Korean)

Lee, Byung-Wook. 2010. The Change of Modern Korean Buddhist Social Participation Thought. The Asian Journal of Religion and Society 1/1: 37-65. (In Korean) 
Park, No-Ja. 2004. The National Discourse of the Time of Enlightenment and the "Others" in It. In The Shaping of Korean Modernity: The Introduction of Modern Concepts during the Korean Enlightenment Period (1895-1910). Edited by the Research Institute of Korean Culture, Ewha Womans University. Seoul: Somyung Books, pp. 223-56. ISBN 895626096693810. (In Korean)

Park, Jin Y. 2010a. Introduction: Buddhism and Modernity in Korea. In Makers of Modern Korean Buddhism. Edited by Jin Y. Park. Albany: SUNY Press, pp. 1-15.

Park, Pori. 2010b. A Korean Buddhist Response to Mdernity: Manhae Han Yongun's Doctrinal Reinterpretation for His Reformist Thought. In Makers of Modern Korean Buddhism. Edited by Jin Y. Park. Albany: SUNY Press, pp. 41-59.

Shim, Jae-Ryoung. 1989. On the General Characteristics of Korean Buddhism: Is Korean Buddhism Syncretic? Seoul Journal of Korean Studies 2: 147-57.

Shim, Jae-Ryoung. 2000. Is Korean Buddhism a United Buddhism? The Buddhist Review. 3. Available online: http:/ / www.budreview.com/news/articleView.html?idxno=304 (accessed on 13 August 2018). (In Korean)

You, Young-Yul. 1985. A Study on Chi-ho Yun during the Time of Enlightenment. Seoul: Hangilsa Books. (In Korean)

Yun, Jong-Gab. 2009. One Mind Harmonization Thought of Wonhyo and Dialogues of TongBulgyo Dialogues (sic.). Korean Association of National Thought 3/2: 87-123. (In Korean)

(c) 2018 by the authors. Licensee MDPI, Basel, Switzerland. This article is an open access article distributed under the terms and conditions of the Creative Commons Attribution (CC BY) license (http:/ / creativecommons.org/licenses/by/4.0/). 